\title{
Nateglinide Stimulates Glucagon-Like Peptide-1 Release by Human Intestinal L Cells via a $K_{\mathrm{ATP}}$ Channel-Independent Mechanism
}

\author{
Yoshiro Kitahara, ${ }^{*}$ Kyoko Miura, Reiko Yasuda, Haruka Kawanabe, Shimpei Ogawa, and \\ Yuzuru ETO \\ Exploratory Research Laboratories, Ajinomoto Pharmaceuticals Co., Ltd.; 1-1 Suzuki-cho, Kawasaki-ku, Kawasaki \\ 210-8681, Japan. \\ Received November 8, 2010; accepted February 10, 2011; published online February 18, 2011
}

\begin{abstract}
A reduced incretin effect is one of the well-known characteristics of patients with type 2 diabetes, and impaired release of glucagon-like peptide-1 (GLP-1) has been reported to be at least partly involved. In this study, we investigated the effect of nateglinide on GLP-1 release in vivo and in vitro. The GLP-1 level in the portal blood at $20 \mathrm{~min}$ after oral administration of nateglinide to Wistar rats was about twice that in vehicle-treated rats. To clarify whether this effect of nateglinide was related to direct stimulation of intestinal cells, in vitro studies were performed using human intestinal L cells (NCI-H716). Nateglinide stimulated GLP-1 release in a concentrationdependent manner from $500 \mu \mathrm{M}$, along with transient elevation of the intracellular calcium level. However, diazoxide, nitrendipine, and dantrolene did not block this effect of nateglinide. In addition, the major metabolite of nateglinide, tolbutamide, and mitiglinide, all of which augment insulin secretion by the pancreatic islets, had no effect on GLP-1 release by this cell line. On the other hand, capsazepine significantly inhibited the promotion of GLP-1 release by nateglinide in a concentration-dependent manner. These findings indicate that nateglinide directly stimulates GLP-1 release by intestinal $L$ cells in a $K_{\text {ATP }}$ channel-independent manner. A novel target of nateglinide may be involved in increasing intracellular calcium to stimulate GLP-1 release, e.g., the transient receptor potential channels. Taken together, the present findings indicate that promotion of GLP-1 release from intestinal $L$ cells may be another important mechanism by which nateglinide restores early-phase insulin secretion and regulates postprandial glucose metabolism.
\end{abstract}

Key words glucagon-like peptide-1; nateglinide; intestinal L cell; $K_{\mathrm{ATP}}$ channel

The incretin effect is markedly reduced in patients with type 2 diabetes, mainly due to defective glucagon-like peptide-1 (GLP-1) secretion from the intestinal L cells in response to stimulation by various nutrients. ${ }^{1,2)}$ This leads to impairment of early-phase insulin secretion after food intake and consequently results in postprandial hyperglycemia and hyperlipidemia. ${ }^{3-6)}$

GLP-1 is an incretin hormone that is released by intestinal $\mathrm{L}$ cells following their stimulation by nutrients, ${ }^{7,8}$ and it promotes glucose-stimulated insulin secretion by pancreatic $\beta$ cells. GLP-1 has also been reported to have various other beneficial effects, such as promoting $\beta$-cell proliferation, ${ }^{9)}$ suppressing glucagon release ${ }^{10)}$ suppressing food intake, ${ }^{11,12)}$ slowing gastric emptying, ${ }^{13,14)}$ and cardiovascular protection. ${ }^{15)}$ Therefore, restoration of GLP-1 secretion by intestinal $\mathrm{L}$ cells could be an important new therapeutic option for the management of metabolic syndrome. Although the exact mechanism of GLP-1 secretion by intestinal L cells remains to be elucidated, the sulfonylurea receptor 1 (SUR1) $/ K_{\text {ATP }}$ channel, ${ }^{16,17)} \mathrm{Na}^{+} /$glucose co-transporter 1 (SGLT1), ${ }^{18)}$ glucose transporter 2 (GLUT2), ${ }^{19)}$ sweet taste receptor, ${ }^{20)}$ TGR5 ${ }^{21)}$ and G-protein coupled receptors (GPRs) ${ }^{22-25)}$ have all been reported to be involved in this process. In the present study, we investigated the effect of nateglinide on GLP-1 secretion by human intestinal $\mathrm{L}$ cells.

Nateglinide is a short-acting insulin secretagogue with a rapid effect, which restores early-phase insulin secretion in patients with type 2 diabetes by rapidly binding to SUR $1^{26-30)}$ and thus suppresses postprandial hyperglycemia. It has been unclear whether or not GLP-1 is involved in these effects of nateglinide. Recently, Duffy et al. reported that nateglinide increases the plasma GLP-1 level by inhibiting dipeptidyl peptidase IV (DPP IV), ${ }^{31)}$ but the influence of nateglinide on GLP-1 secretion is still unknown. Therefore, we investigated the effect of nateglinide on GLP-1 secretion in vivo by monitoring GLP-1 levels in the portal venous blood after oral administration of nateglinide to normal Wistar rats. We also conducted an in vitro study to assess the direct effect of nateglinide on GLP-1 secretion by human intestinal L cells (NCI-H716).

\section{MATERIALS AND METHODS}

Animals Male Goto-Kakizaki (GK) rats and male Wistar rats (6 weeks old) were purchased from Japan SLC Inc. (Hamamatsu, Japan). The animals were housed in individual polycarbonate cages with woodchip bedding, and were provided with food and water ad libitum. The animal room was maintained on a 12-h light/dark cycle (7 a.m.-7 p.m.: dark; 7 p.m. -7 a.m.: light), with a temperature range of $22 \pm 1{ }^{\circ} \mathrm{C}$ and a relative humidity of $55 \pm 5 \%$, throughout the experimental period. These animal experiments were performed in accordance with the Guiding Principles for the care and use of laboratory animals approved by the Japanese Pharmacological Society. In addition, this study was approved by the Animal Care and Use Committee of Ajinomoto Pharmaceuticals Co., Ltd.

Influence of a GLP-1 Antagonist (Exendin 9-39) on the Hypoglycemic Effect of Nateglinide After an overnight fast, GK rats or Wistar rats were administered $10 \mathrm{mg} / \mathrm{kg}$ of sitagliptin (a DPP IV inhibitor) orally at $60 \mathrm{~min}$ before receiving an oral glucose load. At 60 min after sitagliptin administration, either the vehicle $(0.5 \%$ methylcellulose $)$, $50 \mathrm{mg} / \mathrm{kg}$ of nateglinide, or $0.5 \mathrm{mg} / \mathrm{kg}$ of glimepiride was ad- 
ministered by oral gavage with or without subcutaneous injection of the GLP-1 antagonist exendin 9-39 (24 nmol/ $\mathrm{kg})$, and $2 \mathrm{~g} / \mathrm{kg}$ of glucose was given orally immediately after drug administration. Blood samples were collected from the tail vein to measure the blood glucose and plasma insulin levels.

Effect of Nateglinide on the Plasma GLP-1 Level in Vivo Male Wistar rats (10 weeks old) were used to investigate the plasma GLP-1 profile after nateglinide administration. A catheter was inserted into the portal vein of each rat under pentobarbital anesthesia, after which the proximal end of the catheter was tunneled subcutaneously and brought out on the back. Four days after surgery, it was confirmed that spontaneous movement of these rats had recovered to normal, and then the effect of oral nateglinide on the plasma GLP-1 level was investigated. After an overnight fast, the DPP IV inhibitor sitagliptin $(10 \mathrm{mg} / \mathrm{kg})$ was administered orally at $60 \mathrm{~min}$ prior to nateglinide administration in order to inhibit GLP-1 degradation. ${ }^{32}$ Then nateglinide $(50 \mathrm{mg} / \mathrm{kg})$ was administered by oral gavage and the GLP-1 level in the portal venous blood was monitored. The plasma levels of active forms of GLP-1 (GLP-1 (7-37) and GLP-1 (7-36 amide)) were measured by enzyme-linked immunosorbent assay (ELISA) (LINCO, Billerica, MA, U.S.A.).

Cell Culture and GLP-1 Secretion Studies Human enteroendocrine NCI-H716 cells were obtained from the American Type Culture Collection (Manassas, VA, U.S.A.), and were maintained in suspension culture as instructed by the supplier. Two days before each experiment, the cells were seeded in 96-well plates pre-coated with poly-L-lysine $\left(1 \times 10^{5}\right.$ cells /well). On the day of the experiment, the culture medium was replaced by assay buffer (146 mM NaCl, $5 \mathrm{~mm}$ $\mathrm{KCl}, 1.5 \mathrm{~mm} \mathrm{CaCl}_{2}, 1 \mathrm{~mm} \mathrm{MgSO}_{4}, 20 \mathrm{~mm} N$-(2-hydroxy- ethyl)-piperazine- $N^{\prime}$-(2-ethanesulfonic acid) (HEPES), 5.6 $\mathrm{mM}$ glucose, $2 \mathrm{mg} / \mathrm{ml}$ bovine serum albumin, and $10 \mu \mathrm{M}$ sitagliptin, $\mathrm{pH}$ 7.4) with or without test agents and inhibitors, and the cells were incubated for $1 \mathrm{~h}$ at $37^{\circ} \mathrm{C}$. Then the GLP-1 level in the assay buffer was measured by ELISA (LINCO, Billerica, MA, U.S.A.).

Intracellular $\mathrm{Ca}^{2+}$ Imaging Human enteroendocrine NCI-H716 cells were incubated with $5 \mu \mathrm{M}$ Calcium-4 (Calcium-4 assay kit, Molecular Devices (Sunnyvale, CA, U.S.A.)) for $45-60 \mathrm{~min}$, after which the intracellular calcium response to nateglinide stimulation was assessed with an image analyzer (FlexStation, Molecular Devices) and dedicated software.

Statistical Analysis Results are expressed as the mean S.E.M. Statistical analysis was performed with StatView software (version 5.0, SAS Institute, Cary, NC, U.S.A.). Differences were evaluated by the unpaired Student's $t$-test or one-way analysis of variance (ANOVA), followed by Dunnett's test. Statistical significance was accepted at $p<0.05$.

\section{RESULTS}

It is well-known that nateglinide restores impaired earlyphase insulin secretion in patients with type 2 diabetes. $^{26)}$ It is also well-known that GK rats show impairment of earlyphase insulin secretion and hyperglycemia after an oral glucose load. ${ }^{27)}$ We previously reported that restoration of earlyphase insulin secretion by nateglinide was also detected in GK rats. ${ }^{27)}$ In this study, we confirmed that nateglinide restores early-phase insulin secretion and suppresses the increase of blood glucose in these rats (Figs. 1A, B). Intriguingly, we found that restoration of early-phase insulin secretion in GK rats was partially suppressed by injection of the

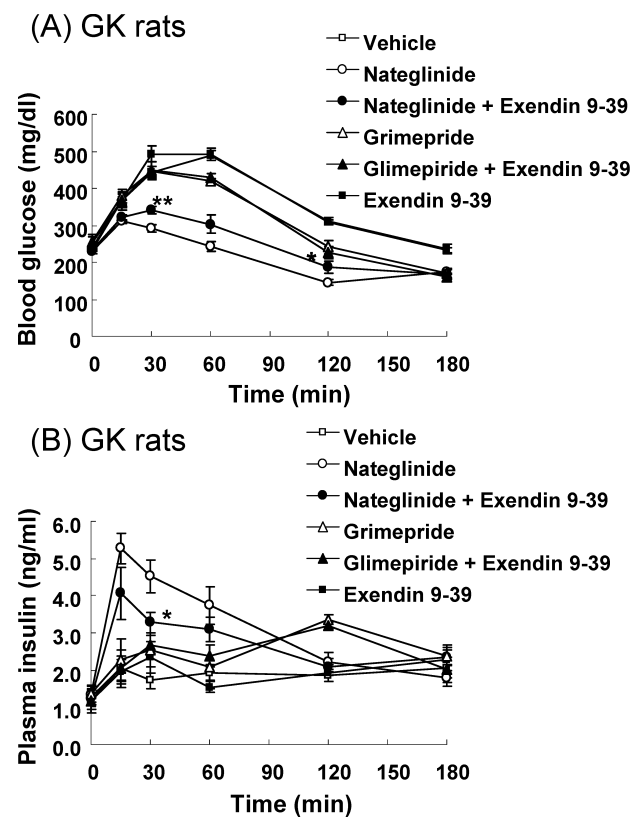

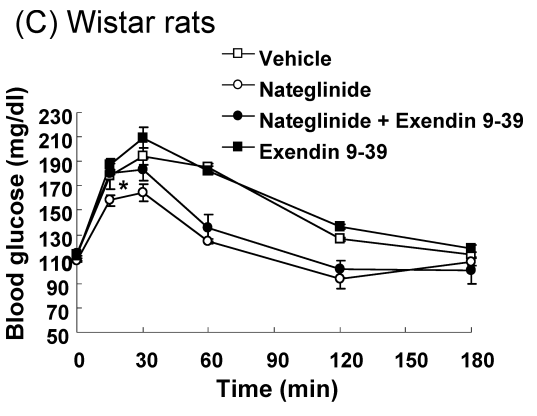

(D) Wistar rats

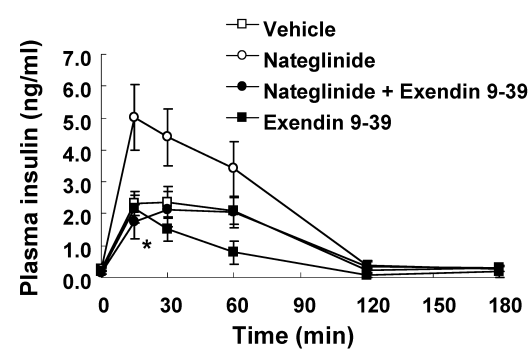

Fig. 1. Influence of Exendin (9-39) on the Insulinotropic Action of Nateglinide

(A, B) After an overnight fast, $2 \mathrm{~g} / \mathrm{kg}$ of glucose was administered to GK rats by oral gavage with either $50 \mathrm{mg} / \mathrm{kg}$ of nateglinide or $0.5 \mathrm{mg} / \mathrm{kg}$ of glimepiride. Exendin (9-39) was administered subcutaneously at $15 \mathrm{~min}$ before the oral glucose load. The DPP IV inhibitor sitagliptin ( $10 \mathrm{mg} / \mathrm{kg}) \mathrm{was}$ administered to block degradation of GLP-1 at $60 \mathrm{~min}$ before glucose administration. Blood samples were collected from the tail vein at the indicated times, and the blood glucose and plasma insulin levels were measured. (C, D) After an overnight fast, $2 \mathrm{~g} / \mathrm{kg}$ of glucose was administered to normal Wistar rats by oral gavage with either the vehicle or $50 \mathrm{mg} / \mathrm{kg}$ of nateglinide. Exendin (9-39) was administered subcutaneously at $60 \mathrm{~min}$ before the oral glucose load, and the same procedures as described in (A) and (B) were performed. Mean \pm S.E.M., $n=5$. $* p<0.05, * * p<0.01 v s$. nateglinide (Student's $t$-test). 


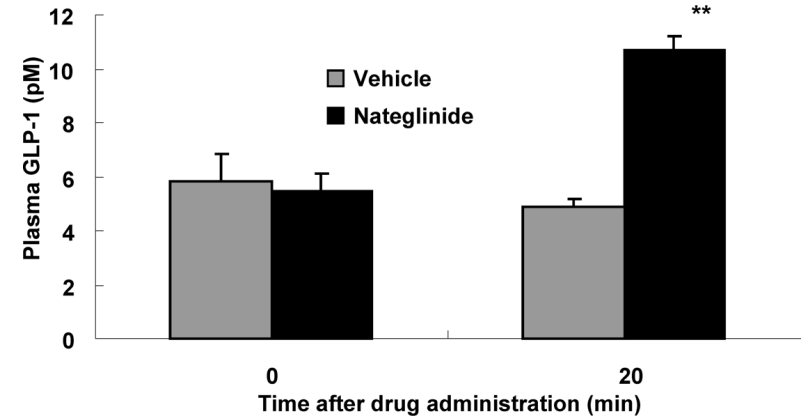

Fig. 2. Changes of Plasma GLP-1 after Oral Administration of Nateglinide

After an overnight fast, either $50 \mathrm{mg} / \mathrm{kg}$ of nateglinide or the vehicle was administered by oral gavage, and blood samples were collected from the portal vein at each indicated time. The DPP IV inhibitor sitagliptin $(10 \mathrm{mg} / \mathrm{kg})$ was administered to inhibit GLP-1 degradation at 60 min before glucose administration. GLP-1 levels were measured by ELISA. Mean \pm S.E.M., $n=5$. $* * p<0.01 v$ s. vehicle (Student's $t$-test).

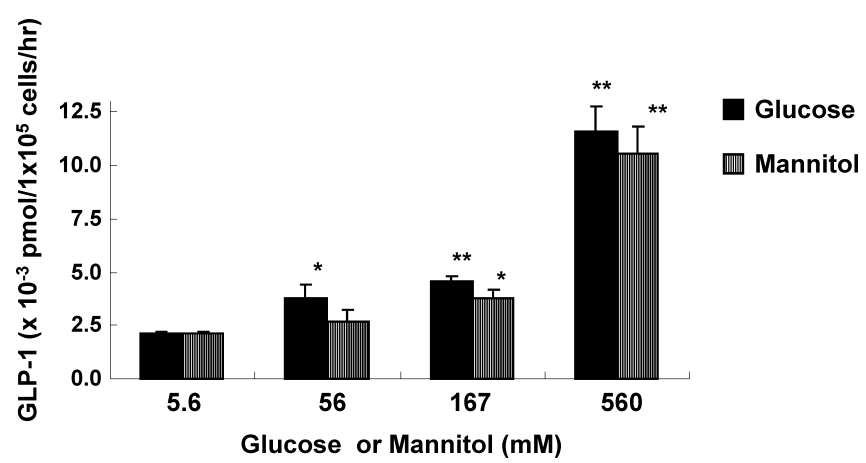

Fig. 3. Effect of Glucose and Mannitol on GLP-1 Secretion by NCI-H716 Cells

NCI-H716 cells $\left(1 \times 10^{5} /\right.$ well $)$ were incubated with either glucose $(5.6,56,167$, or $560 \mathrm{~mm}$ ) or mannitol (at the same concentrations) for $1 \mathrm{~h}$, after which the GLP-1 level in the culture medium was measured by ELISA. Mean \pm S.E.M., $n=3$. $* p<0.05$, $* * p<0.01 v s$. basal glucose $(5.6 \mathrm{~mm})$ (Dunnett's test).

GLP-1 antagonist exendin (9-39) prior to administration of nateglinide, and this also partly inhibited its glucose-lowering effect. In contrast, the sulfonylurea-type insulin secretagogue glimepiride induced a later phase of insulin secretion than nateglinide, and this effect was not influenced by exendin (9-39). These findings suggest that an incretin effect is at least partially involved in the restoration of early-phase insulin secretion by nateglinide. Since the influence of exendin (9-39) on the effect of nateglinide was also observed in normal Wistar rats (Figs. 1C, D), we next investigated whether oral administration of nateglinide induced GLP-1 secretion in normal Wistar rats.

The profile of GLP-1 levels in the portal blood was monitored after oral administration of nateglinide $(50 \mathrm{mg} / \mathrm{kg})$. The DPP IV inhibitor sitagliptin $(10 \mathrm{mg} / \mathrm{kg})$ was administered first, and nateglinide was given by oral gavage at $60 \mathrm{~min}$ after sitagliptin. At $20 \mathrm{~min}$ after nateglinide administration, the GLP-1 level in the portal blood showed an increase to about twice that before administration, while treatment with sitagliptin alone had no effect on the plasma GLP-1 level (Fig. 2). These data indicate that oral administration of nateglinide induced GLP-1 secretion, since an effect of nateglinide on GLP-1 was observed even when DPP IV activity was already inhibited by sitagliptin. Finally, we investigated the direct effect of nateglinide on GLP-1 secretion by intestinal L cells using a human intestinal L cell line (NCI-

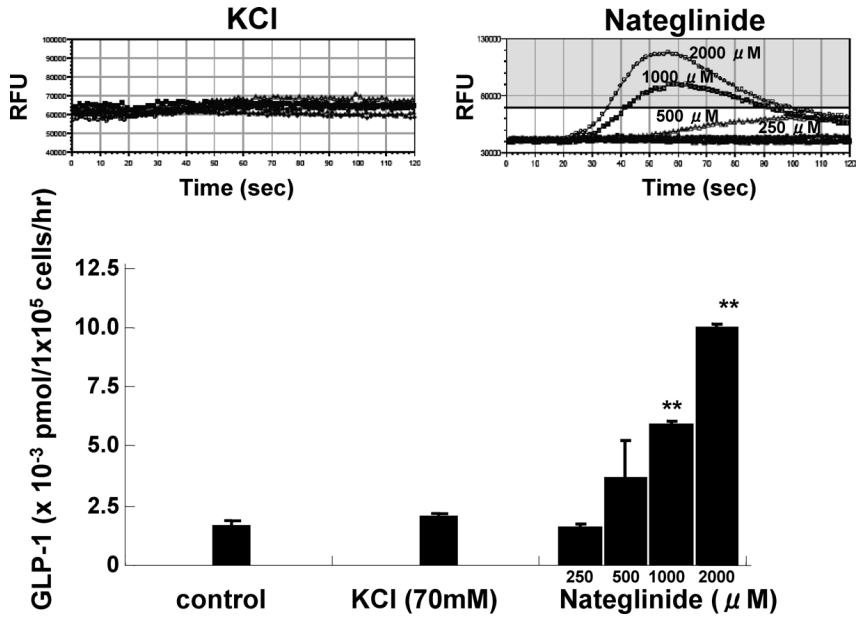

Fig. 4. Effect of Nateglinide on GLP-1 Release by NCI-H716 Cells

NCI-H716 cells $\left(1 \times 10^{5} /\right.$ well $)$ were incubated with $250,500,1000$, or $2000 \mu \mathrm{M}$ nateglinide or $70 \mathrm{~mm} \mathrm{KCl}$ for $1 \mathrm{~h}$, after which the GLP-1 level in the culture medium and the intracellular calcium level were measured. Mean \pm S.E.M., $n=3 . * * p<0.01 v s$. control (Dunnett's test).

H716).

Since glucose is known to be a major stimulant of GLP-1 secretion, we tested the effect of glucose on GLP-1 secretion by this cell line. GLP-1 release from the cells was stimulated by $56 \mathrm{~mm}$ glucose without an osmotic effect, since the same concentration of mannitol had no influence on GLP-1 secretion (Fig. 3). However, stimulation with $70 \mathrm{~mm} \mathrm{KCl}$, which would be expected to induce membrane depolarization, did not increase the intracellular calcium level and did not induce GLP-1 release (Fig. 4). These findings indicate that the NCIH716 cell line does not have normal glucose-sensing machinery like pancreatic $\beta$-cells. However, nateglinide stimulated GLP-1 release by this cell line in a concentrationdependent manner (Fig. 4). Concurrent with this effect of nateglinide, there was transient elevation of the intracellular calcium level (Fig. 4). However, neither a $K_{\text {ATP }}$ channel opener (diazoxide) nor a voltage-dependent calcium channel inhibitor (nitrendipine) had any impact on induction of GLP1 release from these cells by nateglinide (Fig. 5). Dantrolene, a ryanodine receptor inhibitor, also had no impact on nateglinide-induced GLP-1 secretion. The concentrations of these three inhibitors tested in the present study are known to inhibit elevation of the intracellular calcium level in pancreatic $\beta$-cells. ${ }^{33,34)}$ We also investigated the effect on GLP-1 secretion of other insulin secretagogues that act on SUR1 (Fig. 6). Mitiglinide is also known to induce early-phase insulin secretion, but it did not induce GLP-1 secretion by NCIH716 cells. In addition, tolbutamide that is known to bind on the same site of SUR1 as nateglinide failed to induce GLP-1 release by this cell line. Furthermore, a major metabolite of nateglinide (M1), ${ }^{35,36)}$ which induced insulin release from rat pancreatic islets at the same concentration as nateglinide itself (Fig. 7), did not induce GLP-1 secretion by NCI-H716 cells (Fig. 6). These findings indicate that the effect of nateglinide on GLP-1 secretion by this cell line is exerted via a SUR $1 / K_{\text {ATP }}$ channel-independent pathway. Intriguingly, we found that capsazepine, a selective inhibitor of the transient receptor potential channel ${ }^{37)}$, partially blocked the induction of GLP-1 secretion by nateglinide (Fig. 8). 

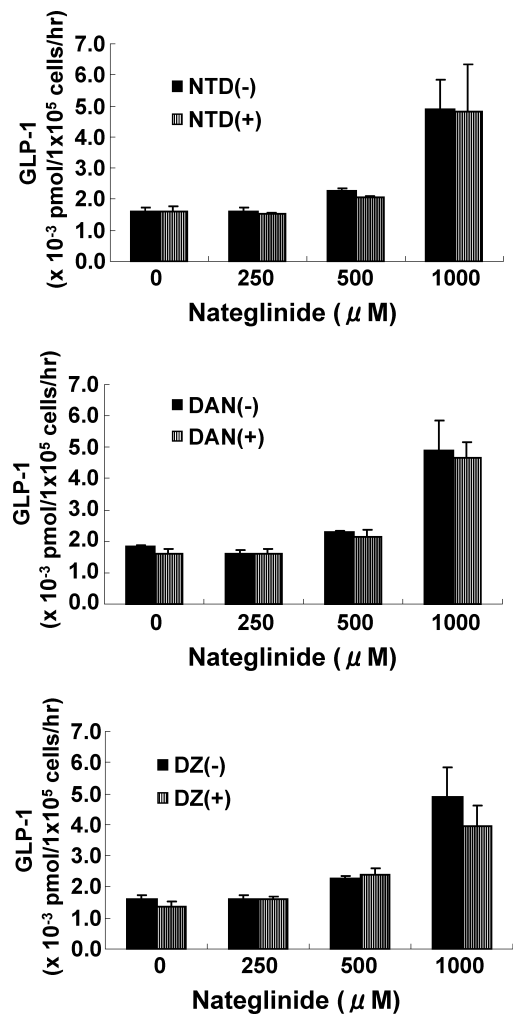

Fig. 5. Effect of Diazoxide, Nitrendipine, and Dantrolene on NateglinideInduced Secretion of GLP-1 by NCI-H716 Cells

NCI-H716 cells $\left(1 \times 10^{5} /\right.$ well $)$ were incubated with each concentration of nateglinide with or without diazoxide (DZ, $200 \mu \mathrm{M})$, nitrendipine (NTD, $1 \mu \mathrm{M})$, or dantrolene (DAN, $1 \mu \mathrm{M}$ ) for $1 \mathrm{~h}$, after which the GLP-1 level in the culture medium was measured by ELISA. Mean \pm S.E.M., $n=3$.
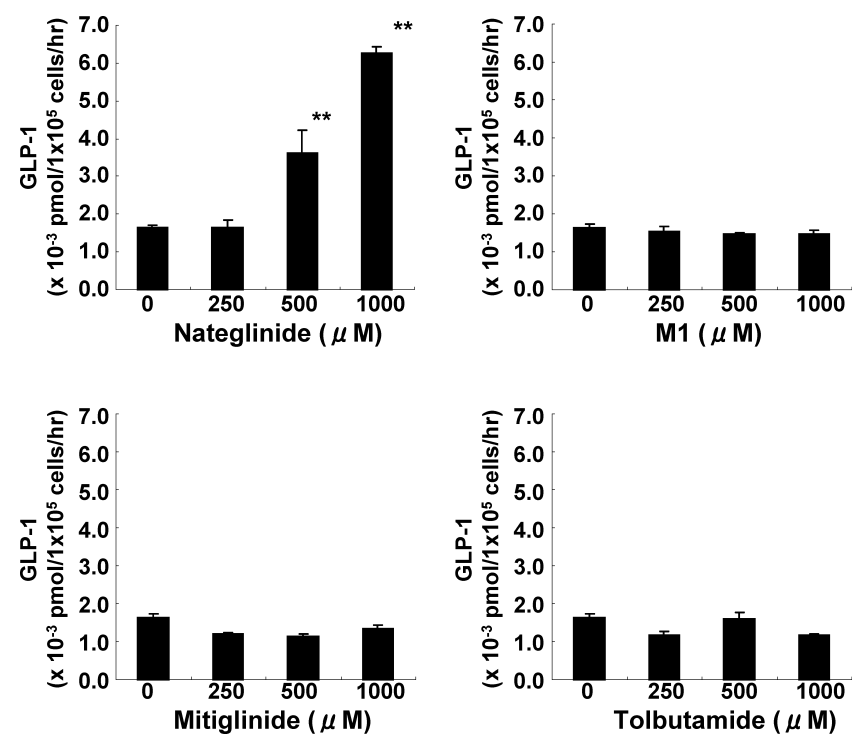

Fig. 6. Effect of the Major Metabolite of Nateglinide (M1), Tolbutamide, and Mitiglinide on GLP-1 Release by NCI-H716 Cells

NCI-H716 cells $\left(1 \times 10^{5} /\right.$ well $)$ were incubated with each concentration of the major metabolite of nateglinide (M1), tolbutamide, or mitiglinide for $1 \mathrm{~h}$, after which the GLP-1 level in the culture medium was measured by ELISA. Mean \pm S.E.M., $n=3$. $* * p<0.01 v s .0 \mu \mathrm{M}$ nateglinide (Dunnett's test).

\section{DISCUSSION}

Impaired GLP-1 secretion in response to nutrients leads to impairment of the incretin effect in patients with type 2 dia-

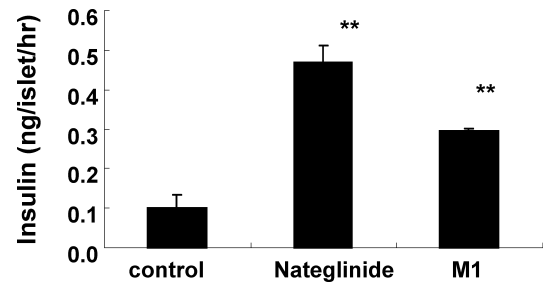

Fig. 7. Insulinotropic Effect of Nateglinide or M1 on Isolated Rat Pancreatic Islets

Pancreatic islets isolated from Wistar rats were incubated in KRBH buffer containing $30 \mu \mathrm{M}$ of nateglinide or $\mathrm{M} 1$ for $1 \mathrm{~h}$, after which the insulin level in the buffer was measured by ELISA. Mean \pm S.E.M., $n=4 . * * p<0.01 v s$. control (Dunnett's test).

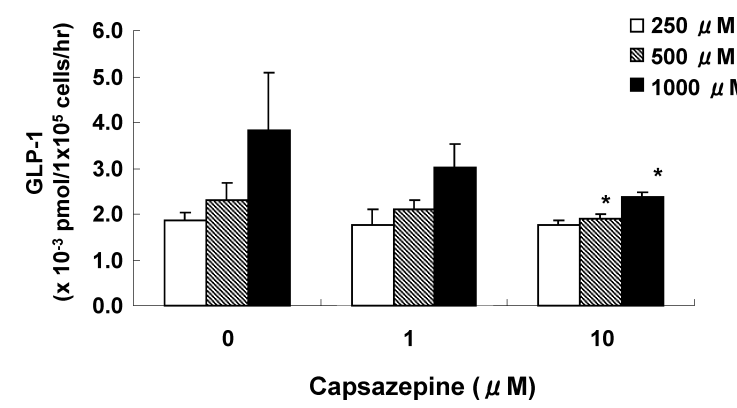

Fig. 8. Effect of Capsazepine on Nateglinide-Induced Secretion of GLP-1 by NCI-H716 Cells

NCI-H716 cells $\left(1 \times 10^{5} /\right.$ well $)$ were incubated with each concentration of nateglinide and capsazepine for $1 \mathrm{~h}$, after which the GLP-1 level in the culture medium was measured by ELISA. Mean \pm S.E.M., $n=3 . * p<0.05 v s .0 \mu$ m capsazepine (Dunnett's test).

betes, ${ }^{1-4)}$ but the detailed mechanism of GLP-1 secretion still remains to be elucidated. Since it has been reported that the glucose-sensing machinery of intestinal L cells is similar to that found in pancreatic $\beta$-cells, ${ }^{16,17)}$ closure of $K_{\text {ATP }}$ channels in L cells is expected to play a crucial role in GLP-1 secretion. Although tolbutamide has been reported to induce GLP-1 secretion by GLUTag cells, ${ }^{17)}$ the effect of sulfonylureas on GLP-1 secretion in vivo is still unclear. In this study, we found that oral administration of nateglinide, an insulin secretagogue acting on SUR1, increased the portal blood GLP-1 level in normal Wistar rats. Since the plasma drug concentration after administration of $50 \mathrm{mg} / \mathrm{kg}$ of nateglinide in vivo was almost comparable to the therapeutic plasma concentration range of nateglinide in humans, ${ }^{35)}$ it is likely that enhancement of GLP-1 secretion is at least partially involved in the hypoglycemic effect of nateglinide.

Duffy et al. reported that intraperitoneal injection of nateglinide increases the plasma GLP-1 level through inhibition of DPP IV in diabetic mice. ${ }^{31)}$ According to their findings, nateglinide is not supposed to stimulate the apical side of enteroendocrine cells. However, our study revealed that oral administration of nateglinide increased the plasma GLP1 level even after inhibition of DPP IV by sitagliptin, indicating that nateglinide induces GLP-1secretion by intestinal cells. Since Tso and his colleague reported that high GLP-1 levels can be detected in intestinal lymph, ${ }^{38-40)}$ it may be necessary to measure GLP-1 in the intestinal lymph after oral administration of nateglinide to evaluate its in vivo effect on GLP-1 secretion more precisely.

As further evidence that GLP-1 secretion is enhanced by nateglinide, we demonstrated a direct effect on GLP-1 secretion by a human intestinal L cell line (NCI-H716 cells). 
Nateglinide induced GLP-1 secretion by this cell line in a concentration-dependent manner. Taking into consideration that the therapeutic plasma concentration range for insulin secretion by nateglinide and that for in vitro activity is 10 $100 \mu \mathrm{M},{ }^{28,35)}$ a high concentration of nateglinide was needed to induce GLP-1 secretion by these cells. However, if this drug is acting on apical side of the small intestine, it may be likely to act in such a high concentrations. In addition, the increase of intracellular calcium after nateglinide stimulation was only transient and the LDH level of the culture medium was unchanged (data not shown). Furthermore, this effect was not observed with mitiglinide, tolbutamide, and a major metabolite of nateglinide at the same concentration range, all of which act on the SUR $1 / K_{\text {ATP }}$ channel and stimulate insulin secretion by pancreatic $\beta$-cells. Therefore, although the mechanism by which nateglinide promotes GLP-1 release by NCI-H716 cells remains to be investigated, the effect seems to be highly specific to this drug. Reimann and Gribble reported that the $K_{\mathrm{ATP}}$ channel plays an important role in GLP1 secretion and that tolbutamide enhances GLP-1 secretion from GLUTag cells, ${ }^{17)}$ probably via closure of the $K_{\text {ATP }}$ channel as occurs in pancreatic $\beta$-cells. However, tolbutamide had no effect on NCI-H716 cells in the present study and nateglinide induced GLP-1 secretion in a diazoxide-independent and nitrendipine-independent manner. Therefore, although it is still unclear whether or not this cell line lacks $K_{\text {ATP }}$ channel activity and/or coupling of the channel to cellular excitation, it seems that nateglinide stimulated GLP-1 secretion by these cells via an SUR $1 / K_{\text {ATP }}$ channel-independent mechanism. Shigeto et al. reported that a SUR $1 / K_{\text {ATP }}$ channel-independent and ryanodine receptor-dependent mechanism is partially involved in the increase of intracellular calcium in pancreatic $\beta$-cells in response to nateglinide. ${ }^{33)}$ In the present study, however, dantrolene had no impact on the influence of nateglinide on NCI-H716 cells. Therefore, there may be unknown mechanisms involved in the increase of intracellular calcium in intestinal L cells by nateglinide. In this study, capsazepine partially suppressed the effect of nateglinide, suggesting that receptor-activated ion channels other than the voltage-dependent calcium channel, such as transient receptor potential channels, may be involved in the stimulation of GLP-1 release by nateglinide. Taken together, these results suggest that nateglinide may also be useful for research into a novel mechanism of GLP-1 secretion by enteroendocrine cells.

In summary, although there are limitations (as described above) to keep in mind when interpreting the current results, we demonstrated that nateglinide stimulates GLP-1 secretion both in vivo and in vitro. Therefore, restoration of the incretin effect may be involved in the improvement of earlyphase insulin secretion by nateglinide in patients with type 2 diabetes. However, this effect of nateglinide should be confirmed in type 2 diabetic patients. In addition, the physiologic role of nateglinide-enhanced GLP-1 secretion in regulating pancreatic $\beta$-cell function, glucagon secretion, appetite, and cardiovascular function also needs to be investigated.

Acknowledgment We thank Ms. Megumi Murakami for her technical assistance.

\section{REFERENCES}

1) Knop F. K., Vilsboll T., Hojberg P. V., Larsen S., Madsbad S., Volund A., Holst J. J., Krarup T., Diabetes, 56, 1951-1959 (2007).

2) Holst J. J., Vilsboll T., Deacon C. F., Mol. Cell Endocrinol., 297, 27 136 (2009).

3) Rask E., Olsson T., Soderberg S., Holst J. J., Tura A., Pacini G., Ahren B., Metabolism, 53, 624-631 (2004).

4) Nauck M. A., Meier J. J., Regul. Pept., 128, 135-148 (2005).

5) Deacon C. F., Diabetes Obes. Metab., 9 (Suppl. 1), 23-31 (2007).

6) Mortensen L. S., Hartvigsen M. L., Brader L. J., Astrup A., Schrezenmeir J., Holst J. J., Thomsen C., Hermansen K., Am. J. Clin. Nutr., 90, 41-48 (2009).

7) Reimer R. A., J. Endocrinol., 191, 159-170 (2006).

8) Tolhurst G., Reimann F., Gribble F. M., J. Physiol., 587, 27-32 (2009).

9) Maida A., Hansotia T., Longuet C., Seino Y., Drucker D. J., Gastroenterology, 137, 2146-2157 (2009).

10) Hare K. J., Knop F. K., Asmar M., Madsbad S., Deacon C. F., Holst J. J., Vilsboll T., J. Clin. Endocrinol. Metab., 94, 4679-4687 (2009).

11) Talsania T., Anini Y., Siu S., Drucker D. J., Brubaker P. L., Endocrinology, 146, 3748-3756 (2005).

12) Tang-Christensen M., Vrang N., Larsen P. J., Int. J. Obes. Relat. Metab. Disord., 25 (Suppl. 5), S42-S47 (2001).

13) Linnebjerg H., Park S., Kothare P. A., Trautmann M. E., Mace K., Fineman M., Wilding I., Nauck M., Horowitz M., Regul. Pept., 151, 123-129 (2008).

14) DeFronzo R. A., Okerson T., Viswanathan P., Guan X., Holcombe J. H., MacConell L., Curr. Med. Res. Opin., 24, 2943-2952 (2008).

15) Noyan-Ashraf M. H., Momen M. A., Ban K., Sadi A. M., Zhou Y. Q., Riazi A. M., Baggio L. L., Henkelman R. M., Husain M., Drucker D. J., Diabetes, 58, 975-983 (2009).

16) Nielsen L. B., Ploug K. B., Swift P., Orskov C., Jansen-Olesen I., Chiarelli F., Holst J. J., Hougaard P., Porksen S., Holl R., de Beaufort C., Gammeltoft S., Rorsman P., Mortensen H. B., Hansen L., Eur. J. Endocrinol., 156, 663-671 (2007).

17) Reimann F., Gribble F. M., Diabetes, 51, 2757-2763 (2002)

18) Gribble F. M., Williams L., Simpson A. K., Reimann F., Diabetes, 52, 1147-1154 (2003).

19) Cani P. D., Holst J. J., Drucker D. J., Delzenne N. M., Thorens B., Burcelin R., Knauf C., Mol. Cell Endocrinol., 276, 18-23 (2007).

20) Jang H. J., Kokrashvili Z., Theodorakis M. J., Carlson O. D., Kim B. J., Zhou J., Kim H. H., Xu X., Chan S. L., Juhaszova M., Bernier M., Mosinger B., Margolskee R. F., Egan J. M., Proc. Natl. Acad. Sci. U.S.A., 104, 15069-15074 (2007).

21) Katsuma S., Hirasawa A., Tsujimoto G., Biochem. Biophys. Res. Commun., 329, 386-390 (2005).

22) Hirasawa A., Tsumaya K., Awaji T., Katsuma S., Adachi T., Yamada M., Sugimoto Y., Miyazaki S., Tsujimoto G., Nat. Med., 11, 90-94 (2005).

23) Overton H. A., Fyfe M. C., Reynet C., Br. J. Pharmacol., 153 (Suppl. 1), S76-S81 (2008)

24) Chu Z. L., Carroll C., Alfonso J., Gutierrez V., He H., Lucman A., Pedraza M., Mondala H., Gao H., Bagnol D., Chen R., Jones R. M., Behan D. P., Leonard J., Endocrinology, 149, 2038-2047 (2008).

25) Hara T., Hirasawa A., Sun Q., Sadakane K., Itsubo C., Iga T., Adachi T., Koshimizu T. A., Hashimoto T., Asakawa Y., Tsujimoto G., Arch. Pharmacol., 380, 247-255 (2009).

26) Uchino H., Niwa M., Shimizu T., Nishiyama K., Kawamori R., Endocrine J., 47, 639-641 (2000).

27) Kitahara Y., Miura K., Takesue K., Mine T., Wada R., Uchida Y., Ito S., Yagihashi S., Metabolism, 51, 1452-1457 (2002).

28) Chachin M., Yamada M., Fujita A., Matsuoka T., Matsushita K., Kurachi Y., J. Pharmacol. Exp. Ther., 304, 1025-1032 (2003).

29) Barnett A. H., Anderson D. M., Shelley S., Morgan R., Owens D. R., Diabetes Obes. Metab., 6, 104-113 (2004).

30) Mine T., Miura K., Kajioka T., Kitahara Y., Metabolism, 57, 140-148 (2008).

31) Duffy N. A., Green B. D., Irwin N., Gault V. A., McKillop A. M., O’Harte F. P., Flatt P. R., Eur. J. Pharmacol., 568, 278-286 (2007).

32) Aoki K., Masuda K., Miyazaki T., Togashi Y., Terauchi Y., Endocrine $J ., 57,667-672$ (2010).

33) Shigeto M., Katsura M., Matsuda M., Ohkuma S., Kaku K., J. Phar- 
macol. Exp. Ther, 322, 1-7 (2007).

34) Ikeda Y., Iguchi H., Nakata M., Ioka R. X., Tanaka T., Iwasaki S., Magoori K., Takayasu S., Yamamoto T. T., Kodama T., Yada T., Sakurai T., Yanagisawa M., Sakai J., Biochem. Biophys. Res. Commun., 333, $778-786(2005)$

35) Weaver M. L., Orwig B. A., Graham E. D., Chin J. A., Shapiro M. J., Mcleod J. F., Mangold J. B., Drug Metab. Dispos., 29, 415-421 (2001).

36) Varanasi K. K., Sridhar V., Potharaju S., Shraddha R., Sivakumar S. P., Sabapathi S. K., Satheeshmanikandan T. R., Kumar V. V., J. Chro- matogr. B Analyt. Technol. Biomed. Life Sci., 865, 91-98 (2008)

37) Cahusac P. M., J. Peripher. Nerv. Syst., 14, 300-309 (2009).

38) D’Alessio D., Lu W., Sun W., Zheng S., Yang Q., Seeley R., Woods S. C., Tso P., Am. J. Physiol. Regul. Integr. Comp. Physiol., 293, R2163R2169 (2007)

39) Kindel T. L., Yang Q., Yoder S. M., Tso P., Am. J. Physiol. Gastrointest. Liver Physiol., 296, G168-G174 (2009).

40) Yoder S. M., Yang Q., Kindel T. L., Tso P., Am. J. Physiol. Gastrointest. Liver Physiol., 297, G299—G305 (2009). 